\title{
PENYELESAIAN KREDIT MACET PADA UNIT KORPRI KANTOR GUBERNUR SUMATERA BARAT
}

\author{
Kiki Trisna Safitri, Romi Susanto \\ Akademi Keuangan dan Perbankan "Pembangunan" (AKBP) Padang \\ romisusanto46@gmail.com
}

\begin{abstract}
The purpose of this research is to find out how bad credit is resolved at the Korpri Unit of the Governor of West Sumatra, for 2015-2019. The research data were taken from the accountability reports of the managers and supervisors. The settlement of bad credit in cooperatives is by using the Non Performing Loan (NPL) method. We can see the results of bad credit settlement in 2018 experiencing bad credit, namely Non Performance Loans of 38\% so this is not healthy for cooperatives and in 2019 experiencing a decrease in non-performing loans (NPL) by 24\%. For the settlement of bad credit, namely by rescheduling (rescheduling), approaching the debtor again by communicating by telephone or orally, or by using warning letters I, II and III to the debtor, and also directly visiting the debtor's house.
\end{abstract}

Keywords: Bad Credit in cooperatives, Non Performing Loans (NPL)

\section{PENDAHULUAN}

Koperasi adalah suatu susunan dari tata ekonomi nasional, hal tersebut berarti merupakan kegiatan koperasi. Koperasi ini turut mengambil sesuatu agar tercapainya kehidupan ekonomi yang sejahterah, baik untuk masyarakat disekitarnya maupun untuk orang-orang yang menjadi anggota perkumpulan itu sendiri. Koperasi ini suatu perkumpulan untuk terjadi adanya sebagai perkumpulan kesejahteraan bersma, dari para anggotanya.

Menurut undang-undang No. 25 Tahun 1992 koperasi Indonesia koperasi merupakan suatu badan usaha yang beranggotakan orang-orang atau badan hukum, koperasi melandaskan kegiatannya dengan berdasarkan prinsip koperasi sekaligus sebagai gerakan ekonomi untuk rakyat yang didasarkan atas asas kekeluargaan.

Di Indonesia koperasi ada beberapa jenis salah satunya pada unit korpri kantor Gubernur Sumatera Barat. Kegiatan yang dilakukan koperasi yaitu melakukan penghimpunan dana dari anggota lalu menyalurkan dana tersebut kepada anggota yang membutuhkan. Penyaluran dana ini biasanya lebih dikenal dengan pemberian kredit.

Koperasi ini merupakan lembaga Non Bank, dalam koperasi ini menyediakan pinjaman dan simpanan ke pada anggotanya. Pada saat penulis magang dikoperasi ini berdasarkan penelitian, penulis menemukan permasalahan 
juga tidak lancar yang sudah jatuh tempo namun belum dapat di selesaikan oleh nasabah yang besakutan.

\section{Metode Penelitian}

\section{Metode Pengumpulan Data}

\section{Wawancara}

Adalah suatu percakapan yang melibatkan antara kedua belah pihak, percakapan yang dilakukan oleh dua pihak yaitu pewawancara yang mengajukan pertanyaan. pada penelitian ini pewawancara melakukan wawancara dengan pengurus Unit Korpri Kantor Gubernur Sumatera Barat.

\section{Dokumentasi}

Suatu informasi yang berasal dari catatan penting baik dari lembaga atau organisasi ataupun perorangan. Adapun dokumen yang diperlukan dalam penelitian ini adalah laporan angsuran mogok ( kredit macet ) pada tahun 20152019.

\section{Metode Analisa Data}

Analisis deskriptif yaitu metode analisis yang mendeskripsikan dan menginterpretasikan data hasil penelitian dengan cara membandingkan data hasil penelitian dengan teori-teori yang ada (Lado, 2008). Metode ini digunakan untuk mengetahui apa penyebab kredit macet dan bagaimana cara penyelesain untuk mengatasi kredit macet. Metode ini juga digunakan untuk tahap penilaian pada prosedur pemberian kredit yaitu penilaian prinsip 5C yang meliputi Character, Capacity, Capital, Collateral, Condition dan prinsip 7 P yang meliputi Personality, Party, Purpose, Prospect, Payment, Profitability, Protection (Firdaus, 2001).

\section{HASIL DAN PEMBAHASAN}

Prosedur pemberian kredit menurut RAT KPRI Unit KORPRI Kantor gubernur Sumatera Barat (2018) adalah sebagai berikut:

1. Berstatus sebagai anggota koperasi atau juga calon anggota koperasi.

2. Mengisi formulir atau proposal pengajuan pinjaman dana yang telah disediakan.

3. Nomor pokok wajib pajak (NPWP) untuk pinjaman dana diatas Rp. 50.000.000,-

4. Kartu tanda penduduk (KTP) suami istri dan surat nikah, jika yang sudah menikah.

5. Kartu keluarga (KK), rekening listrik, slip gaji, dan buku pensiun (jika diperlukan).

6. Tidak lupa juga melampirkan berkas-berkas sebagai jaminan, seperti BPKB motor atau mobil, surat kepemilikan tanah, sertifikat deposito, dan lain-lain, jika ingin meminjam dana untuk keperluan bisnis. 
Menurut RAT KPRI Unit KORPRI Kantor gubernur Sumatera Barat (2018) kerdit macet adalah suatu keadaan dimana anggota koperasi tidak mampu membayar kreditnya tepat pada waktunya.

\section{Analisis atau penilaian kredit}

Dalam hal ini penilaian dari Unit Korpri Kantor Gubernur Sumatera Barat akan dicocokan dengan teknik analisis 5C dan 7P memenuhi kredit yang diajukan oleh calon debitur.

a. Personality yaitu menilai calon debitur dilihat dari tingkah lakunya sehari-hari, bagaimana kesehariannya dilingkungan kantor atau saat berada dirumah.

b. Party (golongan) adalah menggolongkan calon debitur ke dalam kelompok menurut kriteria 5C, yaitu:

1. Character atau watak. Menyangkut kepribadian, sifat/watak, kejujuran calon debitur dalam memberikan keyakinan bahwa benarbenar dapat dipercaya.

2. Capacity atau kemampuan untuk membayar angsuran sesuai dengan perjanjian kredit. Kesanggupan debitur tersebut dinilai dari data finasial berupa kitir gaji pegawai tersebut.

3. Capital atau modal yaitu sumber-sumber pembiayaan lainnya untuk memenuhi syarat. Pada Unit Korpri Kantor Gubernur Sumatera Barat menggunakan kitir gaji.

4. Calon debitur memiliki masa depan atau pribadi atau usaha yang cerah (condition). Unit Korpri Kantor Gubernur Sumatera Barat tidak memfokuskan bahwa anggotanya atau calon debitur menggunakan pinjaman untuk usaha. Jadi bisa menyesuaikan tujuan calon debitur dalam mempergunakan pinjaman tersebut. Mengenai kondisi ekonomi, juga dapat dilihat dari rajinnya membayar simpanan wajib dan melihat kondisi keuangan dari kitir gaji calon debitur tersebut.

5. Collateral atau jaminan yang dimiliki oleh calon debitur. Unit Korpri Kantor Gubernur Sumatera Barat sampai saat ini tidak menerapkan jaminan atau agunanan berupa barang, harta bergerak, ataupun harta tidak bergerak. Mengandalkan keuangan kitir gaji pegawai, dari sanalah Unit Korpri Kantor Gubernur Sumatera Barat menilai.

c. Purpose (tujuan) yaitu tujuan calon debitur dalam mengajukan kredit, apakah calon debitur mempunyai aspek sosial yang positif dan apakah kreditnya dipergunakan sesuai dengan tujuan semula.

d. Prosfect yaitu berhubungan dengan usaha atau pekerjaan calon debitur jangka panjang, apakah dapat menguntungkan bagi Unit Korpri Kantor Gubernur Sumatera Barat.

e. Payment (pembayaran) yaitu dilihat dari segi pengembalian kredit dari sumber mana saja. Unit Korpri Kantor Gubernur Sumatera Barat menghitung kemampuan dan kekuatan pada calon debitur untuk membayar kembali kreditnya melalui kitir gaji.

f. Profitability yaitu kemampuan untuk mendapatkan keuntungan. Keuntungan dilihat dari gaji calon debitur setiap bulan yang memang 
sudah ditetapkan, dalam pembayaran hutang kepada Unit Korpri Kantor Gubernur Sumatera Barat.

g. Protection (perlindungan) yaitu apakah kredit yang diberikan tersebut aman melalui suatu perlindungan. Bagi Unit Korpri Kantor Gubernur Sumatera Barat, seluruh calon debitur merupakan pegawai pemerintahan dimana sudah diatur dalam SK, maka calon debitur terikatnya perlindungan dengan pemerintahan. Pembayaran dilakukan secara otomatis pemotongan gaji tiap bulan. Tidak ada jaminan atau agunan sebagai perlindungan terhadap kredit yang diberikan Unit Korpri Kantor Gubernur Sumatera Barat.

\section{Keputusan Kredit}

Pihak koperasi melalui keputusan kredit dapat memutuskan permohonan kredit yang layak untuk diberikan atau tidak. Bagian unit simpan pinjam akan mengajukan persetujuan kepada manajer atau pengurus. Tujuannya yaitu untuk memutuskan apakah permohnan kredit yang diajukan diterima atau tidak.

\section{Pencairan dan Administrasi Kredit}

Setelah semua dokumen dan surat-surat ditandatangani maka proses prosedur pemberian kredit telah selesai, selanjutnya pihak debitur dapat menerima pencairan kredit tersebut yang telah disiapkan oleh kasir. Tahap administrasi kredit yang telah direalisasi baik yang telah ditarik oleh pihak debitur maupun yang belum ditarik akan segera dibukukan dengan mengacu kepada pedoman administrasi dan akuntansi pada Unit Korpri Kantor Gubernur Sumatera Barat.

\section{Penyebab Kredit Macet}

Penyebab kredit macet pada koperasi unit kantor gubernur sumatera barat adalah dimana terjadinya pihak nasabah melakukan pinjaman dengan 2 sumber, jadi pembayaran dari gaji nasabah tidak mencukupi untuk membayar kreditnya, sebelumnya gaji nasabah ini mencukupi untuk membayar kreditnya tapi setelah nasabah melakukan pinjaman ke sumber ke 2 jadi gaji nasabah ini tidak lagi mencukupi pembayaran kreditnya, jadi itulah penyebab terjadinya kredit macet pada koperasi ini.

Menurut Standar Operating Procedur (SOP) KSP/USP untuk Kebijakan Pengembalian dan Jangka Waktu Pinjaman adalah bagaimana cara pengembalian dapat ditentukan berdasarkan sifat penghasilan dari peminjam atau kesepakatan antara KSP/USP Koperasi dengan peminjam, sehingga cara pengembalian pinjaman bervariasi, yaitu gabungan dari :

1. Pemotongan gaji pada pihak peminjam.

2. Peminjam membayar sendiri ke kantor KSP/USP Koperasi.

3. KSP/USP Koperasi melakukan penagihan pada peminjam. 
Dari segi teori dan keadaan yang terjadi Unit Korpri Kantor Gubernur Sumatera Barat dalam pengembalian pinjaman sesuai dan dikatakan teknisnya sama. Kenyataan yang terjadi pada perjalanan dalam melayani kegiatan simpan pinjam untuk para anggota tersebut, tidak dapat dikatakan dengan keadaan lancar.

\section{Faktor internal dan faktor eksternal}

1. Faktor internal

a. Lemahnya aturan dalam prosedur pemberian kredit dilihat dari tahap penilaian, hanya dilakukan dengan pengamatan secara langsung, tanpa ada standar tertulis. Sehingga tidak ada pedoman dalam tahap penilaian di prosedur pemberian kredit.

b. Kelemahan lain dalam persyaratan permohonan pinjaman kredit pegawai hanya menggunakan slip gaji sebagai jaminan, seharusnya jaminan lain perlu dicamtumkan untuk mengantisipasi biaya kerugian jika debitur tidak dapat melunasi kredit tersebut.

2. Faktor eksternal

a. Pinjaman tidak hanya dilakukan di Unit Korpri Kantor Gubernur Sumatera Barat saja tapi juga melakukan pinjaman dilembaga bank lainnya, sehingga terjadinya penimbulan tunggakan pembayaran. Koperasi tidak dapat mengetahui hal tersebut, sehingga koperasi menjadi kebingungan dan kesulitan dalam penagihan karena ternyata peminjam juga memiliki hutang tidak hanya di Unit Korpri Kantor Gubernur Sumatera Barat saja.

b. Selama proses peminjaman belum selesai atau dalam tahap mengangsur, ternyata telah pensiun sehingga akan menyulitkan koperasi dalam pelunasan karena sudah tidak bisa secara otomatis memotong gaji dikarenakan sudah pensiun.

\section{Penyelesain Kredit Macet}

Upaya yang dilakukan pihak Unit Korpri Kantor Gubernur Sumatera Barat dalam menyelesaikan kredit yaitu sebagai berikut.

a. Melakukan pengendalian kredit macet dengan jalan rescheduling (penjadualan kembali) dengan cara mencatat kembali mengenai identitas debitur, serta kredit yang diberikan (tanggal pencairan, pembayaran dan pelunasan, jumlah angsuran pokok dan bunga setiap tanggal pembayaran) itu akan dicatat kembali. Tujuan dari pencatatan kembali yaitu untuk menilai apakah bisa mengembalikan kreditnya, tetapi apabila diberikan sedikit keringanan kepada debitur dengan memperpanjang jangka waktu angsuran atau memperpanjang jangka waktu kreditnya.

b. Melakukan pendekatan kepada debitur dengan berkomunikasi secara lisan jika bertemu diluar koperasi atau juga bisa melalui telepone. Jika tahap ini, debitur hanya merespon tanpa ada tindak lanjut untuk melunasi hutang tersebut. Maka tahap pemberian surat peringatan atau teguran kepada debitur akan menjadi tahap selanjutnya.

c. Jika sebagian atau seluruh tahap tersebut tidak dapat dipenuhi oleh 
debitur sesuai dengan perjanjian kredit dan persyaratan yang ada, pihak koperasi akan melakukan tindakan dengan prosedur, sebagai berikut.

d. Pihak koperasi akan memberikan surat teguran atau peringatan I langsung terhadap debitur. Penjelasan yang akan disampaikan akibat atas keterlambatan tentang jumlah pokok angsuran dan jumlah bunga pinjaman.

e. Jika butiran ini tidak dipenuhi oleh pihak debitur, pengurus koperasi akan menindak lanjuti debitur dengan memberikan surat peringatan atau teguran yang ke II dengan isi surat tersebut atau pernyataan tentang pembayaran pinjuaman yang harus dilunasi.

f. Jika surat ke II, debitur tersebut tidak ada menunjukkan etikad untuk melunasi pinjaman tersebut maka pengurus koperasi memanggil dengan surat ke III yang ditujukan langsung pada debitur dengan tembusan Bupati, Sekda, Inspektorat, Kepala Kantor yang bersangkutan, Bendahara yang bersangkutan pemerintah Sumatera Barat.

g. Pengurus koperasi mendatangi langsung debitur jika dengan surat III debitur tidak datang melunasi pinjamannya keseluruhannya, maka pengurus koperasi mendata kembali secara detail tentang keadaan debitur dengan mengidentifikasi masalah dan menyelesaikannya untuk keputusan akhir. Mengadakan atau melakukan pendekatan secara kekeluargaan kepada debitur dengan terjun langsung kelapangan untuk melakukan penagihan kepada anggota yang lalai menunaikan kewajibannya.

h. Apabila debitur tersebut dalam kategori sudah pensiun, pihak koperasi akan terus berusaha mendatangi atau berusaha mengunjungi debitur tersebut untuk dapat membayar seluruh tagihannya atau pinjamannya. Jika debitur sudah meninggal, pihak koperasi akan mendekatkan diri kepada keluarga yang bersangkutan agar dapat melunasi hutang tersebut.

i. Apabila kedua faktor tersebut ternyata masih saja pelunasan hutang tidak dapat dipenuhi maka dilakukan dengan cara penghapusan. Penghapusan dilakukan jika pihak yang pensiun tersebut, tidak dapat dihubungi, tidak dapat dicari keberadaanya dan pindah tempat tinggal seperti keluar Bali. Alasan lainnya pihak debitur sudah meninggal, pihak keluarga tidak dapat diajak kerja sama untuk dapat melunasi pembayaran tersebut karena memang tidak ada dalam surat perjanjian tidak diwajibkan pihak keluarga bertanggung jawab dalam pelunasan maka akan dilakukan dengan cara penghapusan.

\section{SIMPULAN}

Berdasarkan hasil pada bab sebelumnya bahwa penelitian yang berjudul "Penyelesain Kredit Macet pada Unit Korpri Kantor Gubernur Sumatera Barat” dapat saya simpulkan sebagai berikut :

a. Prosedur pemberian kredit pada Unit Korpri kantor Gubernur Sumatera Barat melalui dengan langkah-langkah yang dimulai dari permohonan kredit, keputusan kredit, pencairan dan administrasi kredit.

b. Penyebab kredit macet pada Unit Korpri kantor Gubernur Sumatera 
Barat yaitu adanya faktor internal dimana lemahnya aturan dalam prosedur pemberian kredit dilihat dari tahap penilaiannya, koperasi hanya melakukan dengan pengamatan langsung, tanpa ada standar tertulis dan faktor eksternal dimana pinjaman tidak hanya melakukan kredit di Unit Korpri kantor Gubernur Sumatera Barat saja tapi juga melukukan pembukaan kredit pada sumber lainnya, sehingga mengalami terjadinya tunggakan atau disebut juga dengan kredit macet.

c. Upaya atau solusi yang dilakukan oleh pihak Unit Korpri kantor Gubernur Sumatera Barat dalam menyelesaikan kredit macet yaitu pengendalian kredit macet dengan jalan rescheduling (penjadualan kembali), pendekatan kembali kepada pihak debitur dengan berkomunikasi lewat telepon atau secara lisan, atau bisa juga menggunakan surat peringatan I, II, dan III kepada debitur, pendekatan secara kekeluargaan kepada debitur dengan berkunjung langsung kerumah peminjam atau pihak debitur.

\section{UCAPAN TERIMA KASIH}

Penulis mengucapkan terima kasih kepada :

1. Kedua orang tua yang senantiasa merawat dan mendidik serta mecurahkan kasih saying kepada penulis.

2. Direktur AKBP beserta prodi AKBP serta bapak ibuk dosen yang telah mendidik dan memberikan ilmu pengetahuan kepada penulis.

3. Selaku ketua umum pada Unit Korpri Kantor Gubernur Sumatera Barat, beserta karyawan/karyawati yang telah berbagi ilmu, dan bersedia meluangkan waktunya untuk membantu penulis dalam memperoleh data serta informasi yang penulis butuhkan dalam penulisan karya ilmiah sederhana ini.

4. Kepada semua pihakk yang telah membantu dalam membuat tugas akhir.

\section{DAFTAR PUSTAKA}

Alanshari, F., \& Marlius, D. (2018). Prosedur Pemberian Kredit KPR Pada PT. Bank Tabungan Negara (Persero) TBK Cabang Pembantu Bukittinggi. https://doi.org/10.31227/osf.io/rsfhc

Andriani, B., \& Susanto, R. (2016). Pengawasan Kredit PT. Bank Perkreditan Rakyat.(BPR) Ophir Pasaman Barat. Akademi Keuangan Dan Perbankan, $1-12$.

Amelia, L., \& Marlius, D. (2018). Pengendalian Kredit Dalam Upaya Menciptakan Bank Yang Sehat Pada PT. Bank Pembangunan Daerah Sumatera Barat Cabang Utama Padang. https://doi.org/10.31227/osf.io/kpc64

Dendawijaya, L. (2002). Manajemen Perbankan. Yogyakarta: Penerbit PT. Bumi Aksara. 
Hasibuan, H., \& Malayu, S.P., (2007). Dasar-dasar Perbankan. Jakarta: Bumi Aksara.

Hermansyah. (2008). Hukum Perbankan Nasional Indonesia. Jakarta: Kencana Prenada Media Group.

Kasmir. (2002). Bank dan Lembaga Keuangan Lainnya. Jakarta: Penerbit PT. Raja Grafindo Persada.

Kuncoro, M., \& Suhardjono. (2002). Manajemen Perbankan Teori dan Aplikasi. Yoyakarta : BPFE.

Muslehuddin, M. (2004). Sistem Perbankan dalam Islam. Jakarta: Rineka Cipta.

RAT Unit KORPRI tahun Buku 2018 Sumatera Barat.

Rivai, V. (2007). Credit Management Handbook. Jakarta: PT. Raja Grafindo Persada.

Puspita, P. (n.d.). Upaya-Upaya Penyelesaian Kredit Macet Oleh Lemabaga Perbankan Terhadap Debitur Wanprestasi. Jurnal Perbankan. 1-17

Shanjaya, A. R., \& Marlius, D. (2017). Peranan Laporan Keuangan Dalam Kebijaksanaan Pemberian Kredit Kepada Calon Nasabah Pada PT. BPR Batang Kapas. https://doi.org/10.31227/osf.io/uxmg6 